\title{
Oxygen-enhanced MRI can accurately identify, quantify and map tumour hypoxia in preclinical models
}

\author{
JPB O'Connor*, JKR Boult, Y Jamin, M Babur, KG Finegan, KJ Williams, AR Reynolds, RA Little, A Jackson, \\ GJM Parker, JC Waterton, SP Robinson \\ From International Cancer Imaging Society Meeting and 15th Annual Teaching Course (ICIS 2015) \\ London, UK. 5-7 October 2015
}

\section{Aim}

There is need for non-invasive methods to identify, quantify and map tumour hypoxia. In this study we used an emerging technology $-\mathrm{R}_{1}$ oxygen enhanced MRI (OEMRI) - to distinguish those tumour sub-regions that respond to hyperoxic gas challenge from refractory subregions. We hypothesised that the proportion of refractory tumour tissue (Oxy-R) would be a robust biomarker of tumour hypoxia across multiple models with different vascular and hypoxic phenotypes.

Methods: OE-MRI signal precision, stability and relationship to tissue $\mathrm{pO}_{2}$ were evaluated in well vascularised renal cancer 786-O xenografts. Dynamic sensitivity of proportional $\mathrm{Oxy}-\mathrm{R}$ to acute changes in hypoxia was evaluated using hydralazine challenge. Relationship of proportional Oxy-R to tissue immunohistochemistry and gadolinium DCE-MRI were explored in parental and drug-resistant 786-O models and in SW620 xenografts.

\section{Results}

Phantom and in vivo experiments demonstrated the accuracy, precision and stability of $R_{1}$ measurement. The proportion of tumour Oxy-R increased significantly following hydralazine challenge $(\mathrm{p}=0.045)$ relative to control. The proportion of tumour with perfused Oxy-R voxels was correlated to chronic hypoxia in well perfused 786-O- $\mathrm{R}$ xenografts(rho $0.810, \mathrm{p}=0.028$ ) and in relatively necrotic SW620 xenografts (rho 0.929, $\mathrm{p}=0.002$ ).

* Correspondence: james.oconnor@manchester.ac.uk

University of Manchester, Oxford Road, Manchester, M13 9PL, UK

\section{Conclusion}

The proportion of tumour perfused Oxy- $\mathrm{R}$ is a robust biomarker of tumour hypoxia. Voxel-wise analysis of dual oxygen and gadolinium challenge has potential to quantify and map tumour hypoxia as prognostic, predictive and pharmacodynamic biomarkers that could facilitate personalised healthcare.

Published: 2 October 2015

doi:10.1186/1470-7330-15-S1-P9

Cite this article as: O'Connor et al:: Oxygen-enhanced MRI can accurately identify, quantify and map tumour hypoxia in preclinical models. Cancer Imaging 2015 15(Suppl 1):P9.

\section{Submit your next manuscript to BioMed Central and take full advantage of: \\ - Convenient online submission \\ - Thorough peer review \\ - No space constraints or color figure charges \\ - Immediate publication on acceptance \\ - Inclusion in PubMed, CAS, Scopus and Google Scholar \\ - Research which is freely available for redistribution

